\title{
Pengembangan Perangkat Pembelajaran Inkuiri Terbimbing Berbasis Aktivitas Hot Pada Tema 8 Subtema 1
}

\author{
Ni Wayan Rati ${ }^{*}$, Ni Kadek Gunayanti² ${ }^{2}$ I Gede Margunayasa ${ }^{3}$, Ni Nyoman Kusmariyatni ${ }^{4}$
}

${ }^{1234}$ PGSD FIP Universitas Pendidikan Ganesha

\author{
ARTICLEINFO \\ Article history: \\ Received 18 August 2019 \\ Received in revised form \\ 19 September 2019 \\ Accepted 25 October 2019 \\ Available online 30 \\ November 2019 \\ Kata Kunci: \\ Berpikir tingkat tinggi, \\ inkuiri terbimbing, \\ perangkat pembelajaran \\ Keywords: \\ Higher order thinking, \\ guided inquiry, learning \\ devices
}

\begin{abstract}
A B S T R A K
Penelitian ini bertujuan untuk menentukan validitas perangkat pembelajaran inkuiri terbimbing berdasarkan kegiatan berpikir tingkat tinggi (HOT) dalam Tema 8 Subtema 1 di kelas IV SD. Penelitian ini merupakan penelitian pengembangan dengan menggunakan model ADDIE, yaitu (1) analisis (analisis), (2) desain (desain), (3) pengembangan (pengembangan), (4) implementasi (implementasi), dan (5) evaluasi (evaluasi) ), tetapi penelitian ini terbatas pada tahap pengembangan karena waktu yang terbatas dalam penelitian. Metode yang digunakan dalam penilaian produk adalah memberikan lembar penilaian kepada pakar pembelajaran, yaitu dua guru dan dua dosen. Produk yang dikembangkan adalah 1 silabus, 6 rencana pelajaran, dan 6 lembar kerja siswa. Nilai rata-rata validitas setiap perangkat pembelajaran adalah silabus 4,60 dengan kualifikasi sangat baik, rencana pelajaran keseluruhan adalah 4,74 dengan kualifikasi sangat baik, dan keseluruhan lembar kerja siswa adalah 4,77 dengan kualifikasi sangat baik. Berdasarkan analisis ini, dapat dikatakan bahwa pengembangan alat pembelajaran inkuiri terbimbing berbasis aktivitas HOT dinyatakan valid.
\end{abstract}

\section{A B S T R A C T}

This study aims to determine the validity of guided inquiry learning devices based on higher order thinking activities (HOT) in Theme 8 of Subtema 1 in grade IV SD. This research is a development research using ADDIE models, namely (1) analysis (analyze), (2) design (design), (3) development (development), (4) implementation (implementation), and (5) evaluation (evaluation), but this research was limited to the development stage due to limited time in research. The method used in product assessment is to provide a assessment sheet to the learning expert, namely two teachers and two lecturers. Products developed are 1 syllabus, 6 lesson plan, and 6 student worksheets. The average score of the validity of each learning device is the syllabus of 4.60 with excellent qualifications, the overall lesson plan is 4.74 with excellent qualifications, and the overall student worksheets is 4.77 with very good qualifications. Based on this analysis, it can be said that the development of HOT activity-based guided inquiry learning tools was declared valid.

\footnotetext{
${ }^{1}$ Corresponding author.

E-mail addresses: niwayan.rati@undiksha.ac.id (Ni Wayan Rati)
} 


\section{Pendahuluan}

Pembelajaran kurikulum 2013 merujuk pada pendidikan abad 21 yang terdiri dari elemen 4C yaitu collaborative, communication, critical thinking, and creativity (Ismail, 2018). 1) collaborative (kolaboratif) yaitu pembelajaran yang dilakukan dengan mendorong siswa untuk saling berinteraksi dan belajar bersama secara berkelompok untuk meningkatkan kemampuan masing-masing siswa (Suryani, 2009). 2) communication (komunikasi) mencakup tentang kemampuan siswa dalam penyampaian pemikiran baik secara lisan maupun tertulis, selain itu siswa mampu menyampaikan opini dan memberikan perintah dengan jelas (Zubaidah, 2016). 3) critical thinking (berpikir kritis) merupakan kemampuan dalam membuat pertimbangan dan mengambil suatu keputusan dengan cara berpikir secara logis, reflektif, sistematis, dan produktif (Hidayah, 2017). 4) creativity (kreatif), siswa hendaknya berpikir secara kreatif sehingga mampu menciptakan sesuatu yang baru atau mengombinasikan beberapa objek berbeda yang berasal dari pemikiran seseorang sehingga mampu memecahkan permasalahan yang dihadapi (Samsiyah, 2015).

Model pembelajaran inkuiri terbimbing merupakan salah satu model pembelajaran yang tepat diterapkan pada kondisi kelas yang kemampuan peserta didiknya bervariasi. Model pembelajaran inkuiri terbimbing (guided inquiry) adalah model pembelajaran yang berpusat pada peserta didik, peserta didik juga dilatih mengembangkan kemampuan berpikir, peserta didik dilatih berpikir kritis. Selain itu, dapat membangkitkan gairah belajar pada peserta didik (Sumarni, 2017).

(dalam Trianto, 2009:166) menyatakan, "pembelajaran inkuiri merupakan suatu rangkaian kegiatan belajar yang melibatkan secara maksimal seluruh kemampuan siswa untuk mencari dan menyelidiki secara sistematis, kritis, logis, analitis sehingga mereka dapat merumuskan sendiri penemuannya dengan penuh percaya diri".Pendapat tersebut didukung Trianto (2009:166) mengemukakan bahwa sasaran utama kegiatan pembelajaran inkuiri adalah (1) keterlibatan siswa secara maksimal dalam proses kegiatan belajar, (2) keterarahan kegiatan secara logis dan sistematis pada tujuan pembelajaran, dan (3) mengembangkan sikap percaya pada diri siswa tentang apa yang ditemukan dalam proses inkuiri (Udiani, 2017).

Proses pembelajaran pada kurikulum 2013 telah menggunakan strategi pendekatan saintifik, sehingga penerapan model pembelajaran harus disesuaikan dengan strategi tersebut. Pendekatan saintifik menuntut siswa untuk aktif dan proses pembelajaran di kelas berpusat pada siswa, sehingga tujuan pembelajaran tercapai dengan baik.

Perangkat pembelajaran yang disiapkan oleh guru hendaknya disesuaikan dengan tuntutan kurikulum 2013 yaitu sesuai dengan Permendikbud No. 22 Tahun 2016 tentang Standar Proses Pendidikan Dasar dan Menengah dan menerapkan strategi pendekatan saintifik. Penerapan pendidikan abad 21 salah satunya adalah kemampuan berpikir tingkat tinggi (higher order thinking skills) yaitu critical thinking (berpikir kritis) dan creativity (kreatif). Dipandang perlu adanya peningkatan kemamapuan berpikir tingkat tinggi dilaksanakan dengan aktivitas higher order thinking (HOT). Perangkat pembelajaran yang disiapkan hendaknya terdiri dari silabus, RPP, dan LKPD.

Kenyataannya, berdasarkan hasil studi dokumen yang dilaksanakan, perangkat pembelajaran yang disiapkan oleh guru terutama di kelas IV Gugus XII Kecamatan Buleleng belum sesuai dengan Permendikbud No. 22 Tahun 2016 dan belum maksimalnya penerapan strategi pendekatan saintifik. Peningkatan kemampuan berpikir tingkat belum diterapkan pada proses pembelajaran yang berlangsung. Pembelajaran masih didominasi oleh guru, sehingga siswa memiliki kesempatan yang sedikit untuk menyampaikan pendapatnya. Perangkat pembelajaran berupa LKPD belum digunakan sebagai media penunjang dalam proses pembelajaran.

Berdasarkan hasil studi dokumen yang dilakukan, perlunya pengembangan perangkat pembelajaran berbasis inkuiri (penemuan). Pembelajaran inkuiri mengutamakan proses berpikir siswa secara kritis dan analitis, untuk menemukan jawaban dari permasalahan yang ditanyakan (Sanjaya, 2012). Model pembelajaran inkuiri terdiri dari tiga jenis, diantaranya 1) inkuiri terbimbing, yaitu guru membimbing siswa selama proses pembelajaran berlangsung, guru memiliki peran sebagai fasilitator untuk mampu mengarahkan siswa kepada suatu diskusi berdasarkan pertanyaan awal yang diberikan guru. Inkuiri terbimbing digunakan pada siswa yang belum memiliki pengalaman dalam pembelajaran inkuiri. 2) inkuiri bebas, yaitu siswa berperan seolah-olah sebagai seorang ilmuwan. Siswa bebas untuk menentukan permasalahan yang akan diselidiki, menemukan dan menyelesaikan masalah secara mandiri, merancang prosedur atau langkah-langkah yang diperlukan. 3) inkuiri bebas yang dimodifikasi, yaitu kolaborasi antara dua model inkuiri terbimbing dan inkuiri bebas (Jauhar, 2011).

Model pembelajaran inkuiri terbimbing berbasis aktivitas higher order thinking (HOT) mampu menumbuhkan kemmapuan berpikir siswa secara kritis, logis, dan sistematis. Aktivitas higher order thinking (HOT) merupakan aktivitas yang menuntut siswa untuk mengembangkan proses berpikir ilmiah 
dengan berpikir secara kritis dan analitis melalui kegiatan analisa, mengevaluasi, dan mencipta. Pengembangan perangkat pembelajaran inkuiri terbimbing berbasis aktivitas higher order thinking (HOT) mampu memberikan siswa keuntungan yaitu memudahkan siswa untuk menggali sendiri konsep-konsep keilmuan berdasarkan permasalahan yang diselidiki.

Penelitian mengenai model pembelajaran inkuiri terbimbing telah dilaksanakan oleh beberapa peneliti yang memiliki kemiripan pada hasil penelitian dengan penelitian ini. Penelitian tersebut yaitu, pertama Suraya (2010) dengan hasil penelitian yaitu perangkat pembelajaran IPA berorientasi model inkuiri menunjukkan bahwa perangkat pembelajaran IPA yang meliputi RPP, Buku Ajar Siswa, LKS, dan Tes Hasil Belajar yang dikembangkan dinyatakan valid dan layak digunakan sebagai perangkat pembelajaran dan efektif untuk melatih keterampilan proses IPA di SD. Kaitannya dalam penelitian ini adalah perangkat pembelajaran RPP dan LKS yang berorientasi model inkuiri dinyatakan valid sehingga layak diimplementasikan di SD.

Penelitian kedua, Nugraha, dkk (2015) menunjukkan bahwa pengembangan perangkat pembelajaran IPA berdasarkan model pembelajaran inkuiri terbimbing meliputi RPP, buku ajar siswa, LKS, tes penguasaan konsep, dan tes keterampilan berpikir kritis dinyatakan valid, praktis, dan efektif sehingga layak untuk diterapkan pada siswa kelas V SD. Kaitannya dengan penelitian ini adalah perangkat pembelajaran yang menggunakan model pembelajaran inkuiri terbimbing dinyatakan valid sehingga layak untuk diimplementasikan pada pembelajaran di kelas. Tujuan penelitian ini adalah mengetahui validitas perangkat pembelajaran inkuiri terbimbing berbasis aktivitas HOT pada Tema 8 Subtema 1 kelas IV SD.

\section{Metode}

Penelitian yang dilakukan ini merupakan jenis penelitian pengembangan, karena peneliti mengembangkan perangkat pembelajaran inkuiri terbimbing berbasis aktivitas HOT yang memiliki nilai valid berdasarkan uji validitas yang dilakukan. Penelitian ini dilakukan pada bulan April-Mei 2019. Pengembangan yang dilakukan menggunakan model ADDIE yaitu 1) analisis (analyze), 2) perancangan (design), 3) pengembangan (development), 4) implementasi (implementation), dan 5) evaluasi (evaluation) (Tegeh \& Jampel 2017). Namun dalam penelitian ini dibatasi hanya sampai pada tahap ketiga yaitu tahap pengembangan (development) karena keterbatasan waktu.

Tahap analisis (analyze) dilakukan atas tiga kegiatan yaitu 1) analisis kebutuhan bertujuan untuk mengetahui perangkat pembelajaran yang ada di sekolah dan telah digunakan dalam pembelajaran di sekolah, 2) analisis karakteristik siswa dilakukan untuk mengetahui secara pasti kondisi siswa yang akan menggunakan silabus, RPP, dan LKPD, 3) analisis kurikulum dilakukan sebagai dasar pengembangan perangkat yang akan disusun melalui analisis standar kompetensi (SK), kompetensi dasar (KD), dan indikator pencapaian tujuan.

Tahap perancangan (design) pada penelitian ini yaitu perancangan perangkat pembelajaran inkuiri terbimbing berbasis aktivitas HOT. Tahapan ini dilakukan dengan merancang Silabus, RPP, dan LKPD, yang selanjutnya dikonsultasikan kepada dosen pembimbing agar dapat diberikan masukan dan perbaikan terhadap draft perangkat pembelajaran.

Tahap pengembangan (development) dilakukan atas beberapa kegiatan yaitu 1) pengembangan perangkat pembelajaran silabus, RPP, dan LKPD yang telah direvisi sesuai masukan dan perbaikan dari dosen pembimbing, 2) validasi perangkat yang dikembangkan harus dinyatakan valid oleh ahli pembelajaran dengan pemberian lembar penilaian, 3) revisi berdasarkan data hasil evaluasi yang dilakukan oleh ahli pembelajaran. Selanjutnya dilakukan analisis untuk mengetahui tingkat kevalidan perangkat pembelajaran yang dikembangkan. Kemudian dilakukan revisi produk seperlunya sesuai dengan arahan oleh ahli pembelajaran.

Desain uji coba dalam penelitian ini dilakukan mulai dari wawancara dan analisis dokumen, pembuatan perangkat pembelajaran inkuiri terbimbing berbasis aktivitas HOT, dan menguji kelayakan produk dengan validasi yang dilakukan oleh ahli pembelajaran yaitu guru dan dosen. Uji kelayakan dilakukan dengan memberikan lembar penilaian kepada ahli pembelajaran untuk menilai perangkat pembelajaran yang dikembangkan, serta memberikan komentar, masukan, dan saran perbaikan. Selanjutnya, dilakukan revisi berdasarkan komentar dan masukan yang diberikan oleh valiator, untuk menghasilkan perangkat pembelajaran yang sempurna.

Subjek dari penelitian ini adalah guru dan dosen sebagai ahli pembelajaran untuk menilai perangkat pembelajaran yang telah dikembangkan. Objek dari penelitian ini adalah kualitas perangkat pembelajaran inkuiri terbimbing berbasis aktivitas HOT yang telah dikembangkan dengan mencari skor rata-rata validitas dari masing-masing perangkat pembelajaran.

Jenis data yang diperoleh dari penelitian ini adalah data kualitatif dan data kuantitatif. Data kualitatif adalah data yang disajikan dalam bentuk tulisan atau uraian berupa komentar, masukan, dan 
saran yang diberikan oleh guru dan dosen sebagai ahli pembelajaran, yang diperoleh melalui review perangkat pembelajaran yang dikembangkan. Data kuantitatif adalah data yang disajikan dalam bentuk angka berupa skor yang diberikan oleh guru dan dosen melalui hasil review perangkat pembelajaran yang dikembangkan.

Metode pengumpulan data dalam penelitian ini adalah metode kuesioner dengan instrumen penelitian adalah rating scale berupa lembar penelitian. Instrumen penilaian yang digunakan pada penelitian ini adalah rating scale berupa lembar penilaian. Instrumen penilaian diuji kelayakannya dengan uji validitas isi setelah diberikan penilaian oleh para pakar menggunakan formula Gregory. Proses penentuan koefisien validitas isi dilakukan dengan memasukkan hasil penelitian dari kedua pakar terhadap kisi-kisi instrumen perangkat dan tes ke dalam tabulasi $2 \times 2$.

Teknik analisis data yang digunakan dalam penelitian pengembangan ini adalah teknik analisis statistik deskriptif kualitatif dan analisis statistik deskriptif kuantitatif. Metode analisis statistik deskriptif kualitatif digunakan untuk mengolah data berupa masukan, tanggapan, kritik, dan saran hasil dari tinjauan oleh ahli pembelajaran terhadap perangkat pembelajaran yang dikembangkan melalui pemberian kuesioner/angket. Hasil analisis kemudian digunakan untuk memperbaiki perangkat pembelajaran yang dikembangkan sehingga menghasilkan perangkat pembelajaran yang sempurna.

Metode analisis statistik deskriptif kuantitatif digunakan untuk mendeskripsikan skor rata-rata dari masing-masing perangkat pembelajaran yang dikembangkan. Skor rata-rata validitas dari masingmasing perangkat berdasarkan skor yang diperoleh dari setiap indikator dapat menggunakan rumus mean (rata-rata). Selanjutnya, skor rata-rata validitas masing-masing perangkat pembelajaran dikonversi dengan Penilaian Acuan Patokan (PAP) skala lima. Perangkat pembelajaran dinyatakan valid apabila hasil rata-rata pada masing-masing perangkat pembelajaran inkuiri terbimbing berbasis aktivitas HOT minimal berada pada kualifikasi baik dengan rentang $3,01<x \leq 4,01$.

\section{Hasil dan Pembahasan}

Hasil analisis data yang diperoleh berdasarkan uji validitas yang telah dilakukan oleh ahli pembelajaran dengan pemberian kuesioner/angket. Hasil analisis data berupa rata-rata skor validitas dari masing-masing perangkat yaitu 1) perangkat pembelajaran silabus memperoleh rata-rata skor validitas sebesar 3,60 dengan kualifikasi sangat baik berdasarkan tabel konversi skala lima, 2) perangkat RPP memperoleh rata-rata skor masing-masing RPP yaitu RPP 1 sebesar 4,6, RPP 2 sebesar 4,72, RPP 3 sebesar 4,73, RPP 4 sebesar 4,77, RPP 5 sebesar 4,84, dan RPP 6 sebesar 4,73. Perbandingan hasil ratarata skor validitas masing-masing RPP dapat dilihat pada Gambar 1.

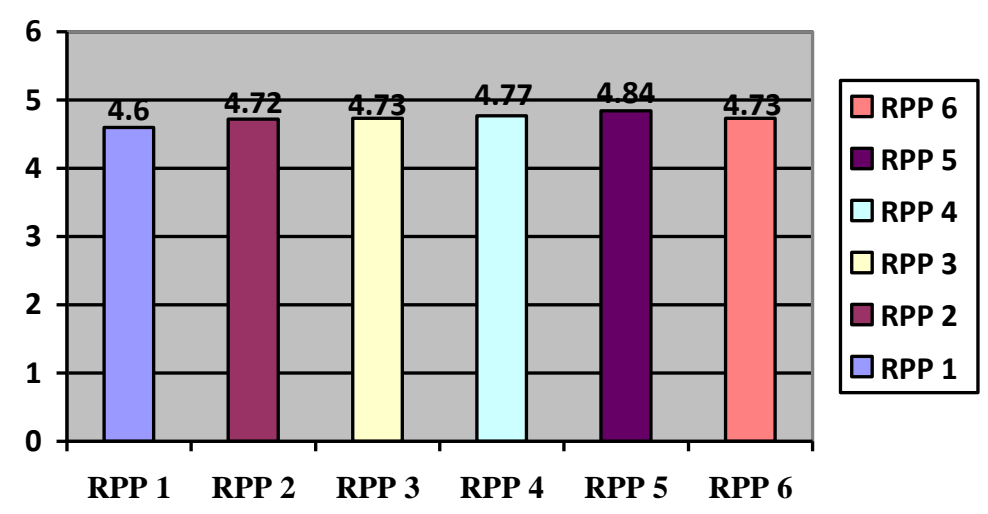

Gambar 1. Grafik Rata-rata RPP

Secara keseluruhan diperoleh rata-rata RPP sebesar 4,74 dengan kualifikasi sangat baik berdasarkan tabel konversi skala lima, 3) Perangkat pembelajaran LKPD memperoleh rata-rata skor validitas pada masing-masing LKPD yaitu LKPD 1 sebesar 4,73, LKPD 2 sebesar 4,75, LKPD 3 sebesar 4,79, LKPD 4 sebesar 4,79, LKPD 5 sebesar 4,77, dan LKPD 6 sebesar 4,81. Perolehan rata-rata skor validitas pada masing-masing LKPD dapat dilihat pada Gambar 2. 


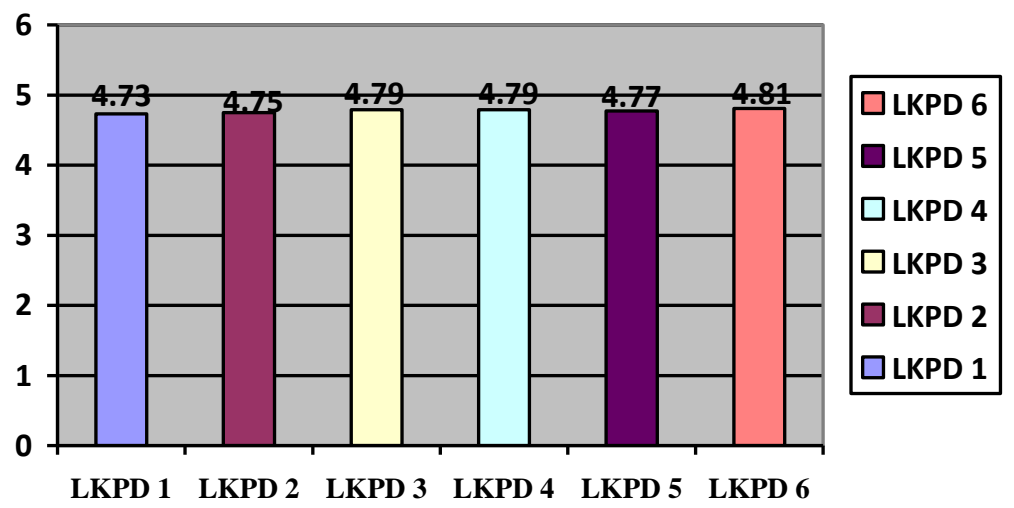

Gambar 2. Grafik Rata-rata LKPD

Secara keseluruhan diperoleh rata-rata LKPD sebesar 4,77 dengan kualifkasi sangat baik berdasarkan tabel konversi skala lima. Berdasarkan hasil analisis rata-rata skor validitas yang telah dilakukan, dapat dinyatakan bahwa hasil rata-rata keseluruhan dari masing-masing perangkat pembelajaran dinyatakan pada kualifikasi sangat baik, berdasarkan pernyataan sebelumnya, dikatakan bahwa perangkat pembelajaran dinyatakan layak dan valid apabila telah memenuhi skor validitas minimal sebesar 3,01 dengan kualifikasi baik.

Berdasarkan deskripsi hasil penelitian yang telah diuraikan sebelumnya, pengembangan perangkat pembelajaran inkuiri terbimbing berbasis aktivitas HOT dengan menggunakan model pengembangan ADDIE melalui tahap analyze, design, development, implementation, dan evaluation. Pemilihan model ini didasari atas pertimbangan bahwa model ini mudah dipahami dan dikembangkan secara sistematik. Kelima tahapan tersebut adalah panduan dalam mengembangkan produk perangkat pembelajaran. Akan tetapi, pada penelitian ini tahapan dari model ADDIE terbatas pada tahap development (pengembangan) karena keterbatasan waktu dalam penelitian.

Pada tahap analisis dilakukan beberapa tahapan yaitu analisis kebutuhan, analisis karakteristik siswa, dan analisis kurikulum. Dari analisis kebutuhan diketahui bahwa masih terbatasnya perangkat pembelajaran yang digunakan oleh guru sebagai sarana untuk mengembangkan proses pembelajaran sehingga siswa mampu belajar dengan menemukan sendiri konsep-konsep keilmuan secara mandiri dengan bimbingan dari guru. Perangkat pembelajaran yang dikembangkan hendaknya disesuaikan dengan hasil dari analisis kebutuhan (Pariatna, 2015). Oleh sebab itu, disusun perangkat pembelajaran yang mampu menciptakan pembelajaran dengan konsep penemuan (inkuiri) dengan aktivitas HOT.

Pada tahap design (desain) dilakukan perencanaan perangkat pembelajaran berupa Silabus, Rencana Pelaksanaan Pembelajaran (RPP), dan Lembar Kegiatan Peserta Didik (LKPD) inkuiri terbimbing berbasis aktivitas HOT. Penyusunan silabus dilakukan dengan unsur-unsur, yaitu 1) komponen silabus, 2) identitas silabus, 3) kompetensi inti, 4) mata pelajaran dan kompetensi dasar, 5) Tema/Subtema, 6) materi pokok, 7) kegiatan pembelajaran, 8) penilaian, 9) alokasi waktu, dan 10) sumber belajar (Permendikbud, 2016). Penyusunan RPP dilakukan atas dasar unsur-unsur yaitu, 1) identitas RPP, 2) tujuan pembelajaran, 3) kompetensi dasar, 4) indikator pencapaian kompetensi, 5) materi pembelajaran, 6) metode pembelajaran, 7) media pembelajaran, 8) sumber pembelajaran, 9) langkah-langkah pembelajaran, dan 10) penilaian hasil belajar (Permendikbud, 2016). Kemudian, penyusunan perangkat LKPD dilakukan dengan unsur-unsur, yaitu 1) sampul LKPD, 2) identitas LKPD, 3) tujuan pembelajaran LKPD, 4) petunjuk kerja, 5) kegiatan LKPD, dan (6) simpulan.

Pada tahap development (pengembangan) dilakukan pengembangan perangkat pembelajaran inkuiri terbimbing berbasis aktivitas HOT yang meliputi Silabus, RPP, dan LKPD. Setelah dikembangkan, perangkat pembelajaran selanjutnya diberikan skor/nilai oleh empat ahli pembelajaran yaitu dua guru dan dua dosen dengan memberikan kuesioner validitas perangkat pembelajaran. Setelah dilakukan penilaian, diperoleh komentar dan saran dari ahli pada masing-masing perangkat pembelajaran. Kemudian, dilakukan revisi berdasarkan masukan yang telah dipertimbangkan untuk menyempurnakan perangkat pembelajaran.

Berdasarkan hasil analisis validitas perangkat, adapun temuan penelitian ini adalah rerata skor dari masing-masing perangkat pembelajaran inkuiri terbimbing berada pada rentang $4,01<x \leq 5,01$ dalam tabel pedoman konversi skala lima dengan kualifikasi "sangat baik". Hasil ini menunjukkan bahwa perangkat pembelajaran inkuiri terbimbing berbasis aktivitas HOT dinyatakan valid, karena nilai valid 
berada minimal pada kualifikasi "baik" (Hayati, 2013). Tinjauan ini didasarkan pada rata-rata dari masing-masing perangkat pembelajaran, yaitu perangkat pembelajaran silabus inkuiri terbimbing berbasis aktivitas HOT memiliki rerata skor validitas sebesar 4,60 berada pada kualifikasi "sangat baik".

Perangkat pembelajaran RPP inkuiri terbimbing berbasis aktivitas HOT memiliki rerata skor validitas sebesar 4,74. Jika dikonversi ke dalam Pedoman Acuan Patokan (PAP) Skala Lima berada pada kualifikasi "sangat baik". Hasil ini menunjukkan bhawa perangkat pembelajaran silabus inkuiri terbimbing berbasis aktivitas HOT dinyatakan valid, karena nilai valid berada minimal pada kualifikasi "baik" (Hayati, 2013).

Perangkat pembelajaran LKPD inkuiri terbimbing berbasis aktivitas HOT memiliki rerata skor validitas sebesar 4,77. Jika dikonversi ke dalam Pedoman Acuan Patokan (PAP) Skala Lima berada pada kualifikasi "sangat baik". Hasil ini menunjukkan bahwa perangkat pembelajaran silabus inkuiri terbimbing berbasis aktivitas HOT dinyatakan valid, karena nilai valid berada minimal pada kualifikasi "baik" (Hayati, 2013). Dari uraian di atas, dapat diketahui dengan jelas bahwa pengembangan perangkat pembelajaran inkuiri terbimbing berbasis aktivitas higher order thinking (HOT) berada pada kualifikasi "sangat baik" dan bernilai valid, sehingga perangkat pembelajaran yang telah dikembangkan layak untuk diimplementasikan di sekolah dasar.

\section{Simpulan dan Saran}

Berdasarkan hasil penelitian dan pembahasan dapat disimpulkan bahwa pengembangan perangkat pembelajaran inkuiri terbimbing berbasis aktivitas higher order thinking (HOT) pada Tema 8 Subtema 1 kelas IV SD, yaitu perangkat pembelajaran silabus dengan skor rata-rata validitas sebesar 4,60. Perangkat RPP dengan rata-rata skor validitas sebesar 4,74. Perangkat LKPD dengan skor rata-rata validitas sebesar 4,77. Secara keseluruhan perangkat pembelajaran inkuiri terbimbing berbasis aktivitas higher order thinking (HOT) berada pada kualifikasi sangat baik.

Berdasarkan proses dan hasil penelitian yang dilakukan, beberapa saran yang disampaikan dalam rangka mengembangkan perangkat pembelajaran adalah sebagai berikut, pertama, kepada guru, dalam melaksanakan proses pembelajaran guru dapat menggunakan perangkat pembelajaran pada penelitian ini sebagai refrensi dalam melaksanakan pembelajaran terutama pada pembelajaran Tema 8 Subtema 1 Kelas IV SD. Guru dapat mengembangkan perangkat pembelajaran yang serupa dengan penelitian ini. Pembelajaran inkuiri terbimbing berbasis aktivitas HOT dapat digunakan pada perangkat pembelajaran pada tema lain. Kedua, kepada kepala sekolah, berkaitan dengan pelaksanaan pembelajaran yang efektif, hendaknya kepala sekolah memfasilitasi guru untuk mengembangakan perangkat pembelajaran, seperti diikutsertakan dalam pelatihan pengembangan perangkat pembelajaran. Ketiga, kepada peneliti lain yang hendak melakukan penelitian pengembangan dapat menjadikan penelitian ini sebagai refrensi. Serta peneliti lain mampu melanjutkan penelitian ini pada tahap implementasi pada penelitian eksperimen.

\section{Daftar Rujukan}

Hayati, M. N., Supardi, K. I., \& Miswadi, S. S. (2013). Pengembangan pembelajaran ipa smk dengan model kontekstual berbasis proyek. Innovative Journal of Curriculum and Educational Technology, Vol 2 No 1.

Hidayah, R., dkk. (2017). Critical Thinking Skill: Konsep Dan Inidikator Penilaian. Taman Cendekia: Jurnal Pendidikan Ke-SD-an, Vol1 No 2, hlm 127-133.

Ismail, R. A. R., \& Ismail, D. (2018). Aplikasi Konsep 4C'pembelajaran Abad Ke-21 dalam Kalangan Guru Pelatih Pengajian Agama Institut Pendidikan Guru Kampus Dato'razali Ismail. Asian People Journal (APJ), Vol 1 No 1, hlm 45-65.

Jauhar, M. (2011). Implementasi PAIKEM dari Behavioristik sampai Konstruktivistik. Jakarta: Prestasi Pustakaraya.

Masalah Matetatika Open-Ended Ditinjau Dari Tingkat Kemampuan Matematika Siswa Sekolah Dasar. PEDAGOGIA: Jurnal Pendidikan, Vol 4 No 1, hlm 23-33. 
Nugraha, A. W., dkk. (2015). Pengembangan Perangkat Pembelajaran IPA Berdasarkan Model Inkuiri Terbimbing untuk Melatihkan Penguasaan Konsep dan Keterampilan Berpikir Kritis Siswa SD. Jurnal Review Pendidikan Dasar: Jurnal Kajian Pendidikan dan Hasil Penelitian, Vol 1 No 1.

Pariatna, I. W. J., Sudria, I. B. N., \& Wasono, N. K. (2017). Pengembangan perangkat pembelajaran inkuiri terbimbing pada topik laju reaksi. Wahana Matematika dan Sains: Jurnal Matematika, Sains, dan Pembelajarannya, Vol 9 No. 1, hlm 38-50.

Samsiyah, N. dan H. E. Rudyanto. (2015). Kemampuan Berpikir Kreatif Dalam Memecahkan Masalah Matetatika Open-Ended Ditinjau Dari Tingkat Kemampuan Matematika Siswa Sekolah Dasar. PEDAGOGIA: Jurnal Pendidikan, Vol 4 No 1, hlm 23-33.

Sanjaya, W. (2012). Strategi Pembelajaran berorientasi Standar Proses Pendidikan. Jakarta: Kencana Prenada Grup

Sumarni, S . 2017. Pengaruh Model Pembelajaran Inkuiri Terbimbing Terhadap Hasil Belajar Kognitif Peserta Didik Di Sma Negeri 01 Manokwari (Studi Pada Pokok Bahasan Kelarutan Dan Hasil Kali Kelarutan) . Jurnal Nalar Pendidikan Volume 5, Nomor 1, Jan-Jun 2017.

Suraya, S. N. (2010). Pengembangan Perangkat Pembelajaran IPA Berorientasi Model Inkuiri untuk Melatihkan Ketrampilan Proses di SD. Jurnal Pendidikan, Vol 16 No 1.

Tegeh, I M. dan I N. Jampel. (2017). Metode Penelitian dan Pengembangan. Singaraja: Universitas Pendidikan Ganesha.

Udiani, Ni Ketut. 2017. Pengaruh Model Pembelajaran Inkuiri Terbimbing Terhadap Hasil Belajar Ipa Dengan Mengendalikan Keterampilan Proses Sains Siswa Kelas Iv Sd No.7 Benoa Kecamatan Kuta Selatan Kabupaten Badung . e-Journal Program Pascasarjana Universitas Pendidikan Ganesha Program Studi Pendidikan Dasar (Vol 7, No 1 Tahun 2017).

Zubaidah, S. (2016). Keterampilan Abad ke 21: Keterampilan yang Diajarkan melalui Pembelajaran. Seminar Nasional Pendidikan dengan tema "Isu-isu Strategis Pembelajaran MIPA Abad", Volume 21 No 10. 